\title{
Spatial distribution and origin of coalbed gases at the working faces of the Velenje Coal Basin, Slovenia, since the year 2000
}

\section{Prostorska porazdelitev in izvor premogovnih plinov raziskanih iz odkopnih območij iz Velenjskega premogovnega bazena, Slovenija od leta 2000}

\author{
Tjaša Kanduči, *, Simon Zavšek², Sergej Jamnikar², Timotej Verbovšek ${ }^{3}$ \\ ${ }^{1}$ Jožef Stefan Institute, Jamova 39, SI - 1000 Ljubljana, Slovenia \\ ${ }^{2}$ Velenje Coal Mine, Partizanska cesta 78, 3320 Velenje, Slovenia \\ ${ }^{3}$ Department of Geology, Faculty of Natural Sciences and Engineering, University of Ljubljana, Privoz 11, 1000 Ljubljana, Slovenia \\ *tjasa.kanduc@ijs.si
}

\begin{abstract}
Geochemical and isotopic monitoring of coalbed gases at the excavation fields of mining areas in Velenje Coal Basin, Slovenia, has been ongoing since the year 2000 with the aim of obtaining better insights into the distribution and origin of coalbed gases. Results from the mining areas Pesje and Preloge (active excavation fields) are presented here from the year 2000 up to the present. Composition and origin of coalbed gases were determined using mass spectrometry at the Jožef Stefan Institute. From a larger database of geochemical samples, 119 samples were used for analysis and spatial presentation in a geographical information system (GIS) environment. We have used geochemical $\left(\mathrm{CH}_{4^{\prime}}\right.$ $\mathrm{CO}_{2}$ and $\left.\mathrm{N}_{2}\right)$ and isotopic $\left(\delta^{13} \mathrm{C}_{\mathrm{CO} 2}\right.$ and $\left.\delta^{13} \mathrm{C}_{\mathrm{CH} 4}\right)$ tracers for geochemical and isotopic characterisation of coalbed gases from the active excavation fields. Concentrations of $\mathrm{CO}_{2}$ and the carbon dioxide-methane indices in the southern part of the basin are higher than in the northern part of the basin due to the vicinity of the active Šoštanj Fault. The value of $\delta^{13} \mathrm{C}_{\mathrm{CH} 4}$ at the active excavation field indicates a bacterial origin, with values greater than $-50 \%$, and only some boreholes show elevated $\delta^{13} \mathrm{C}_{\mathrm{CH} 4}$ quantities as a consequence of the $\mathrm{CO}_{2}$ reduction process in Velenje Coal Basin. The value of $\delta^{13} \mathrm{C}_{\mathrm{CO} 2}$ indicates the bacterial and endogenic origin of carbon.
\end{abstract}

Key words: distribution of coalbed gases, gas origin, JamTveg GIS, excavation fields, Velenje Coal Basin

\section{Izvleček}

Geokemični in izotopski monitoring premogovnih plinov na aktivnih odkopih v rudarskih območjih Velenjskega premogovnega bazena poteka od leta 2000 $\mathrm{z}$ namenom pridobiti vpogled $\mathrm{v}$ porazdelitev in sestavo premogovnih plinov ter njihov izvor. $\mathrm{V}$ tem prispevku predstavljamo geokemične $\left(\mathrm{CH}_{4}, \mathrm{CO}_{2}, \mathrm{~N}_{2}\right)$ in izotopske $\left(\delta^{13} \mathrm{C}_{\mathrm{CO} 2}, \delta^{13} \mathrm{C}_{\mathrm{CH} 4}\right)$ parametre iz rudarskih območij Pesje in Preloge, kjer potekajo aktivni odkopi od leta 2000 do danes. Sestavo in izvor premogovnih plinov smo določili z metodami masne spektrometrije na Institutu Jožef Stefan. Iz večje baze plinskih vzorcev je bilo izbranih 119 vzorcev, ki so bili analizirani in nato prikazani v GIS okolju. Uporabili smo geokemične $\left(\mathrm{CH}_{4}, \mathrm{CO}_{2}, \mathrm{~N}_{2}\right)$ in izotopske sledilce $\left(\delta^{13} \mathrm{C}_{\mathrm{CO} 2}, \delta^{13} \mathrm{C}_{\mathrm{CH} 4}\right)$ za geokemično in izotopsko karakterizacijo premogovnih plinov iz aktivnih odkopov. Koncentracije $\mathrm{CO}_{2}$ in CDMI indeksa v južnem delu bazena so višje v bližini Šoštanjskega preloma v primerjavi s severnim delom bazena. $\delta^{13} \mathrm{C}_{\mathrm{CH} 4}$ na aktivnih odkopih nakazuje bakterijski izvor z vrednostmi nižjimi od $-50 \%$, samo v nekaterih vrtinah so bile zaznane višje vrednosti $\delta^{13} \mathrm{C}_{\mathrm{CH} 4}$, kar je posledica $\mathrm{CO}_{2}$ redukcijskih procesov v Velenjskem premogovnem bazenu. $\delta^{13} \mathrm{C}_{\mathrm{CO} 2}$ kaže na bakterijski in endogeni izvor ogljika.

Ključne besede: porazdelitev premogovnih plinov, izvor plinov, JamTveg GIS, aktivni odkopi, Velenjski premogovni bazen 


\section{Introduction}

The distribution and origin of coalbed gases $\left(\mathrm{CO}_{2}\right.$ and $\left.\mathrm{CH}_{4}\right)$ in Velenje Basin are related to the geological composition of the basin. Geochemical processes have occurred in the basin during its formation (Kanduč and Pezdič, 2005; Kanduč et al., 2012). The geological characteristics of the Velenje Basin are thus crucial for the understanding and interpretation of the distribution of coalbed gases. The aim of this study is to present the concentrations $\left(\mathrm{CO}_{2}\right.$ and $\left.\mathrm{CH}_{4}\right)$ and isotopic compositions of carbon in both the gases $\left(\delta^{13} \mathrm{C}_{\mathrm{CO} 2}\right.$ and $\left.\delta^{13} \mathrm{C}_{\mathrm{CH} 4}\right)$, as well as their spatial distributions. Because the concentrations of coalbed gases change with advance of the working face, we have included available data from the year 2000. Kočar et al. (1987, 1989) investigated elements of safe longwall top coal caving (LTCC) under water-bearing strata at Velenje Coal Mine. Research into the dynamics of longwall excavation and its effects on overburden strata resulted in the formulation of the Criteria of Safe Excavation under water-bearing strata. Technical documentation related to mining operations and technical solutions were assembled according to the guidelines of the Criteria of Safe Excavation under water-bearing strata by the designers at Velenje Coal Mine (Lenart et al., 1996).

\section{Geological setting}

Mining in the Velenje, with one of the thickest single coal seams in the world, has been active for about 140 years. The Velenje coal seam is located in Northern Slovenia near the town of Velenje. The Velenje Basin (Figure 1) formed in the Pliocene to Pleistocene times by polyphase dextral strike-slip faulting at the junction of three tectonic units: the Central Karavanke Mountains, the Southern Karavanke Mountains and the Gorenje-Šoštanj block (Brezigar et al., 1987).

The Velenje Basin is filled with Plio-Pleistocene sediments of terrestrial coarse-grained clastic beds with fine-grained lacustrine clastic sediments, summing to more than $1000 \mathrm{~m}$ thickness. Along the Smrekovec fault at the southern edge of the Basin, andesite bodies lie at the bottom of the Basin. On the northern parts of the Velenje Basin, in the footwall near the Velenje fault, lie Triassic dolomites and limestones (Brezigar et al., 1987). The coal is classified as lignite (Markič and Sachsenhofer, 1997) and lies in a single stratum between the Pliocene clastic sediments. The coal body is lens shaped, about $8.3 \mathrm{~km}$ long and $2.5 \mathrm{~km}$ wide. Under the lignite seam, the Pliocene strata are up to $50 \mathrm{~m}$ thick, consisting of shales, clay, coal and lignite. Above the Pliocene strata lie green sandy silts up to $250 \mathrm{~m}$ thick. The lignite seam, whose thickness can reach $160 \mathrm{~m}$, lies above the footwall. Above the coal seam, a thin layer of marls with lacustrine molluscs is detected, comprising up to 350-m-thick lacustrine strata consisting of clays, marls and silts. These strata are overlain with a 90-m-thick sandy-silty formation. The uppermost part of the basin consists of terrestrial silts, overlain by recent fluvial sediments (Brezigar et al., 1987) (Figure 1). The area of the Velenje Basin was formed by many geological processes, such as magmatic activity, strikeslip reverse faulting and erosion. Heat flow studies suggest that heat flows were elevated in the Velenje area during Oligocene times, as a result of Smrekovec volcanism (Brezigar et al., 1987).

The geochemical and isotopic characterisation of coalbed gases from different excavation fields, with their advance from the Velenje Basin to the boreholes, in the period 2000-2012 has been partly published elsewhere (Kanduč, 2004, Kanduč and Pezdič, 2005; Kanduč et al., 2011; Kanduč et al., 2012, Sedlar et al., 2014, Kanduč et al., 2015). Apart from the gas analysis, several investigations have also been performed on the hydrogeochemical and isotopic processes occurring in groundwater (Kanduč et al., 2014; Urbanc and Lajlar, 2002; Veselič and Pezdič, 1998). Formation waters in Velenje Basin are not trapped within the coal seam, because large amounts of groundwater are extracted from the Velenje Basin aquifers by intensive pumping (strata de-watering) to facilitate underground mining of coal (Vukelič et al., 2016). The groundwater recharging the basin is therefore not in direct contact with the coal seam.

\section{Prior geochemical research on coalbed gas}

The coalbed gas in the Velenje Basin consists of, on average, a mixture of $\mathrm{CO}_{2}$ and $\mathrm{CH}_{4}$. Lignite at 


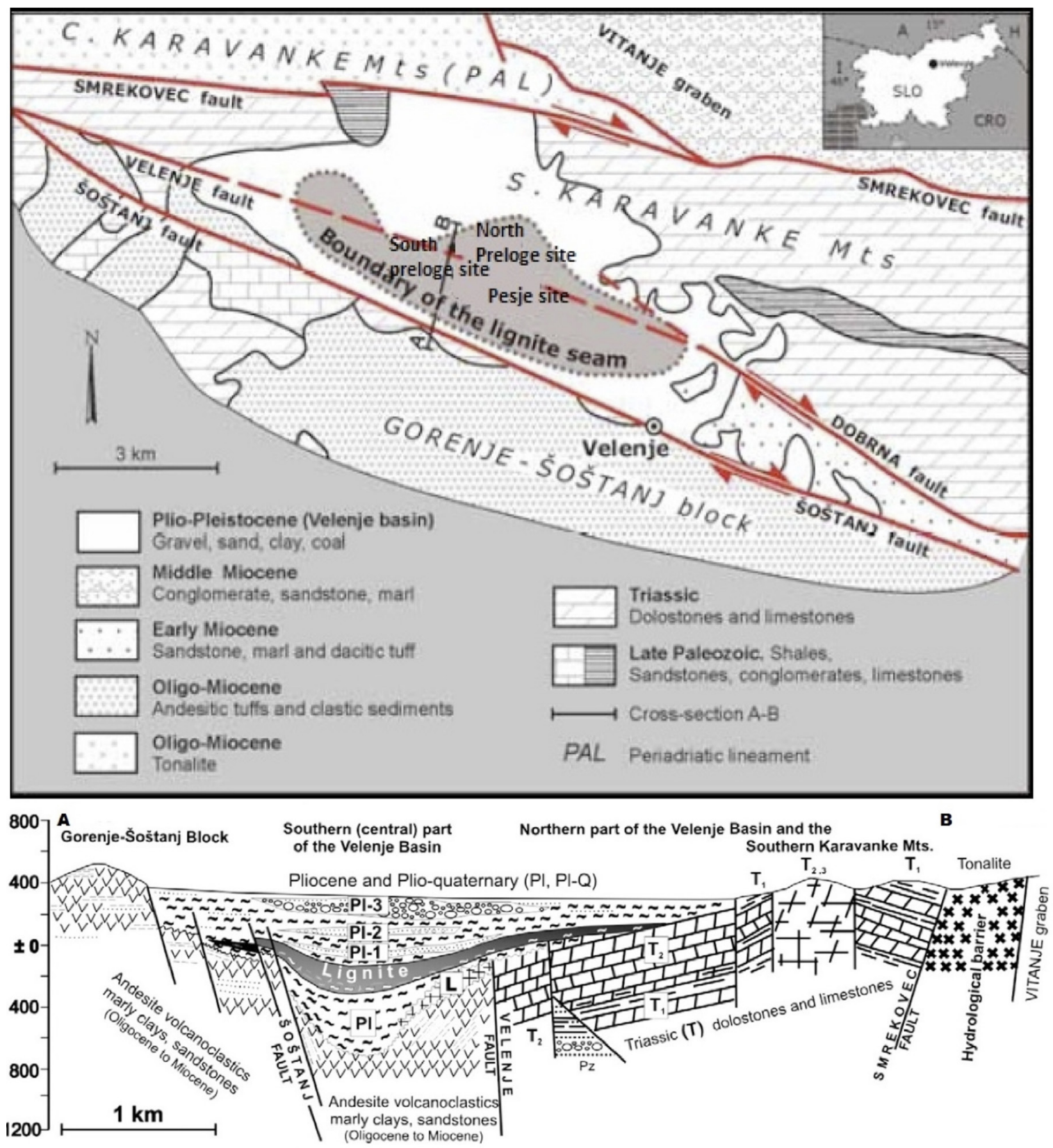

Figure 1: Location of Velenje Basin with geological profile, adapted from Brezigar (1987).

the Velenje Coal Mine has an average coal gas mixture of approximately $\mathrm{CO}_{2}: \mathrm{CH}_{4} \geq 2: 1$ (Kanduč et al., 2011, Kanduč et al., 2015). This ratio is related to the excavation technique known worldwide as the Velenje mining method (Jeromel et al., 2010; Sedlar et al., 2014). The ratio changes with advance of the working face, and sometimes $\mathrm{N}_{2}$ is in excess (Kanduč et al., 2011, Kanduč et al., 2015). When the advance rate of the longwall face is slow (less than $3 \mathrm{~m} /$ day), gas can escape more slowly under the high pressure in the virgin coal. In general, investi- gations have shown an opposite trend between $\mathrm{CO}_{2}$ and $\mathrm{CH}_{4}$ concentrations $\left(R^{2}=0.99\right)$ with the advancement of the working faces (Kanduč et al., 2011, Kanduč et al., 2015). Due to outbursts of coal and gas in the roadways at the working face (Vižintin et al., 2016), the origin of $\mathrm{CO}_{2}$ needed to be established. We have used the ratio of the concentrations of $\mathrm{CO}_{2}$ and $\mathrm{CH}_{4}$, known as carbon dioxide-methane index (CDMI) or the Australian index. This index is defined as $\mathrm{CDMI}=\left[\mathrm{CO}_{2} /\left(\mathrm{CO}_{2}+\mathrm{CH}_{4}\right)\right]$ and is expressed in percentage. The isotopic composition of $\mathrm{CO}_{2}$ 


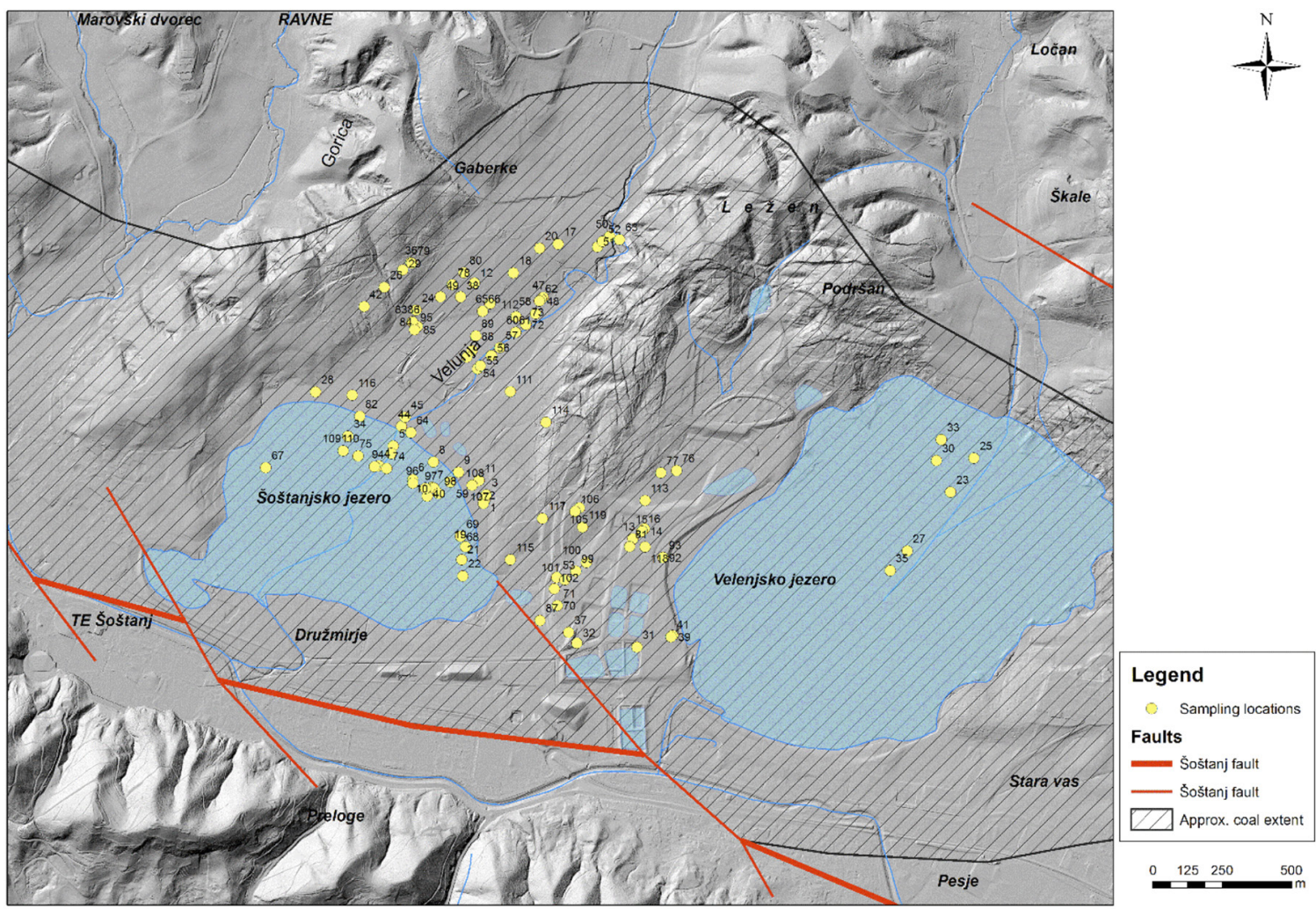

Figure 2. Map of sampling locations of coalbed gases from the lignite seam, from active working faces, from the year 2000. Numbers indicate the consecutive numbers of samples (refer Table 1). Shaded relief is provided by light detection and ranging (LiDAR) data from the Slovenian Environment Agency, available at http://gis.arso.gov.si/evode/profile.aspx?id=atlas_voda_ Lidar@Arso).

in conjunction with the CDMI is often used to infer the origin of $\mathrm{CO}_{2}$ in coal gases (Kotarba, 2001; Smith and Pallasser, 1996). This index was therefore introduced to decipher the origin of $\mathrm{CO}_{2}$ in the Velenje Basin, as in the Bowen and Sydney Basins, Australia (Smith and Gould, 1980; Faiz and Hendry, 2006). Four different types of origin of $\mathrm{CO}_{2}$ are known: endogenic $\mathrm{CO}_{2}, \mathrm{CO}_{2}$ originating from carbonates, $\mathrm{CO}_{2}$ of microbial origin and $\mathrm{CO}_{2}$ originating from headwaters recharging the basin (Kanduč and Pezdič, 2005).

\section{Materials and methods}

\section{Sampling locations}

Sampling of coalbed gas was performed by an operator, e.g. a miner responsible for the underground coalbed gas monitoring. Free gas includes the volatiles filling the pores and the cracks within the coal structure, as well as some gas degassed from the coal during drill- ing and sampling (Kotarba, 2001). Short (3 m) and long boreholes $(25 \mathrm{~m})$ were used for coal gas concentration monitoring; the design of a 25-m-long borehole is described by Jamnikar (2016). Since the year 2000, the length of boreholes has changed and has varied between 3 and $25 \mathrm{~m}$ (Table 1). From a larger database of gas samples, 119 samples were included for this study. As several measurements were taken at the same locations during the investigated period, only the first measurements were taken at any one location. Locations are presented in Figure 2.

After drilling, the capillary tube was inserted in boreholes. "Free gas" (Kotarba, 2001) emitted from the borehole was collected in a $50 \mathrm{~mL}$ plastic syringe, then transferred to a $12 \mathrm{~mL}$ ampoule, which was flushed with coalbed gas and filled under pressure. After sampling of the "free gas" from the boreholes, the ampoules were stored under normal atmospheric conditions until analysis. Seven ampoules were sampled at each location; the third ampoule was 
analysed for chemical composition $\left(\mathrm{CO}_{2}, \mathrm{CH}_{4}\right.$, $\mathrm{O}_{2}, \mathrm{~N}_{2}$ and $\mathrm{Ar}$ ), and other ampoules were used for determination of the isotopic compositions of carbon in $\mathrm{CH}_{4}\left(\delta^{13} \mathrm{C}_{\mathrm{CH} 4}\right)$ and carbon dioxide $\left(\delta^{13} \mathrm{C}_{\mathrm{CO} 2}\right)$.

Data to be analysed were recorded in an Excel spreadsheet, with names of the boreholes, their technical data and geochemical measurements. A local coordinate system was used for the boreholes, with $\mathrm{D} 48 / \mathrm{GK}$ geodetic datum as a base, but with all but the last four digits truncated. Therefore, the local coordinates had to be transformed back to the georeferenced system to be used in the geographical information system (GIS) environment.

\section{Analytical procedures}

Concentrations of $\mathrm{CH}_{4}, \mathrm{CO}_{2}, \mathrm{O}_{2}, \mathrm{~N}_{2}$ and Ar were determined using a homemade mass Nier spectrometer. The method is described in detail in the studies by Kanduč et al. $(2011,2015)$ and Sedlar et al. (2014). Isotopic compositions of $\mathrm{CH}_{4}$ and $\mathrm{CO}_{2}$ were determined using a Europa 20-20 continuous flow isotope ratio mass spectrometer with an automated nitrogen and carbon analyser (ANCA) - trace gas (TG) preparation module. First, water was removed and $\mathrm{CO}_{2}$ was then analysed directly for $\delta^{13} \mathrm{C}_{\mathrm{CO2}}$. For $\mathrm{CH}_{4}$ measurements, $\mathrm{CO}_{2}$ was first removed and then the $\mathrm{CH}_{4}$ was combusted over hot $10 \%$ platinum $\mathrm{CuO}\left(1000^{\circ} \mathrm{C}\right)$. The $\mathrm{CH}_{4}$, completely converted to $\mathrm{CO}_{2}$, was then analysed directly for the isotopic composition of carbon $\left(\delta^{13} \mathrm{C}\right)$. Working standards calibrated to International Atomic Energy Agency (IAEA) reference materials were used, with values of $-4.3 \%$, $3.2 \% 0$ and $-5.2 \%$ for $\mathrm{CO}_{2}$ and values of $-53.4 \%$ and $-47.5 \%$ o for $\mathrm{CH}_{4}$ relative to Vienna Pee Dee Belemnite (VPDB). The analytical precision for carbon isotope composition is estimated to be $\pm 0.2 \%$ or $\mathrm{CO}_{2}$ and $\pm 0.6 \%$ o for $\mathrm{CH}_{4}$. Stable carbon isotopes are presented in the $\delta$ notation relative to VPDB standards and are expressed in parts per million (Coplen, 1996) as follows (O’Neil, 1979):

$\delta\left({ }^{13} C\right)_{S}=\frac{R_{s}-R_{R M}}{R_{R M}} \cdot 1000[\% 0]$

where $R_{\mathrm{s}}={ }^{13} \mathrm{C} /{ }^{12} \mathrm{C}$ ratio in the sample and $R_{\mathrm{RM}}=$ ${ }^{13} \mathrm{C} /{ }^{12} \mathrm{C}$ ratio in the reference material.

\section{Results and discussion}

Due to air contamination within boreholes (ventilation of the coalmine) and the capillary system, samples were reassessed on an air-free basis. The percentage of oxygen in the sampled ampoules was used to calculate the amount of nitrogen, according to the ratio in air $\left(\mathrm{N}_{2}\right)$ $\mathrm{O}_{2}$ ) considering Dalton's law (Atkins, 1994); $\mathrm{CH}_{4}$ migrates faster and $\mathrm{CO}_{2}$ slower. Results show that the major gas components were $\mathrm{CO}_{2}$ and $\mathrm{CH}_{4}$.

All data on coalbed gas composition from the excavation fields of Velenje Basin are summarised in Table 1 . Concentrations vary greatly between the samples, with those of $\mathrm{CO}_{2}$ ranging from $0 \%$ to $95.5 \%, \mathrm{CH}_{4}$ from $0 \%$ to $77.5 \%$ and $\mathrm{N}_{2}$ from $0 \%$ to $80 \%$. Generally, $\mathrm{CO}_{2}$ was the prevailing gas, because its average value was $59 \%$, with $\mathrm{CH}_{4}$ being $30 \%$ and $\mathrm{N}_{2}$ much less, about $11 \%$, of the total composition. The geochemical index CDMI varied from $1 \%$ to $100 \%$; stable isotope ratios varied in the following ranges: $\delta^{13} \mathrm{C}_{\mathrm{CO} 2}$ from $-14.80 \%$ to $+3.19 \%$ and $\delta^{13} \mathrm{C}_{\mathrm{CH} 4}$ from $-74.90 \%$ o to $-19.82 \%$ (Table 1 ).

Using the GIS environment application JamTveg GIS (Verbovšek, 2010; Verbovšek and Vrabec, 2012), we interpreted the distribution of coalbed gases from the mining areas Preloge and Pesje and determined the origin of coalbed gases at the active excavation fields, as well as the exit and delivery roadways.

The distribution of $\delta^{13} \mathrm{C}_{\mathrm{CO} 2}$ in Velenje Basin is presented in Figure 3A. Values of $\delta^{13} \mathrm{C}_{\mathrm{CO} 2}$ up to $-14.80 \%$ are typical for the degradation of organic matter at the northern part of the basin, while values up to $+3.19 \%$ are typical for bacterial gas formed via the $\mathrm{CO}_{2}$ reduction process, as found in previous studies (Kanduč et al., 2012) and observed in the southern part of the basin (Figure 3A).

For endogenic $\mathrm{CO}_{2}$ (thermal degradation of carbonates), a typical value is $-7 \%$ o. For carbonate dissolution in Velenje Basin, values are typically around $-3 \%$ (Kanduč et al., 2012). Organic degradation exhibits values of $-14 \%$, so the source of $\mathrm{CO}_{2}$ in the Velenje Basin can be attributed to bacterial origin, by $\mathrm{CO}_{2}$ reduction. The distribution of $\delta^{13} \mathrm{C}_{\mathrm{CH} 4}$ at the active excavation fields since the year 2000 is shown in Figure 3B. On the northern part of Velenje Basin, 
Table 1. Geochemical composition of coalbed gases and isotopic composition of carbon in $\mathrm{CO}_{2}\left(\delta^{13} \mathrm{C}_{\mathrm{CO} 2}\right)$ and $\mathrm{CH}_{4}\left(\delta^{13} \mathrm{C}_{\mathrm{CH}}\right)$, as well as the CDMI, at the investigated locations. Blank values indicate missing data.

\begin{tabular}{|c|c|c|c|c|c|c|c|c|c|}
\hline No. & Date & $\begin{array}{c}\text { Length } \\
\text { (m) }\end{array}$ & Borehole & $\begin{array}{c}\delta^{13} C_{c 02} \\
(\% 0)\end{array}$ & $\begin{array}{l}\delta^{13} \mathrm{C}_{\mathrm{CH} 4} \\
(\% 0)\end{array}$ & $\begin{array}{c}\text { CDMI } \\
(\%)\end{array}$ & $\mathrm{CH}_{4}(\%)$ & $\begin{array}{l}\mathrm{CO}_{2} \\
(\%) \\
\end{array}$ & $\begin{array}{l}\mathrm{N}_{2} \\
(\%)\end{array}$ \\
\hline 1 & 1.2 .2000 & 3 & $19 \mathrm{~A}$ & -12.05 & -43.06 & 82.52 & 17.25 & 81.44 & 1.31 \\
\hline 2 & 1.2 .2000 & 12 & $\begin{array}{c}\text { j.v.780- } \\
\text { H/2000(IV) }\end{array}$ & -11.80 & -53.53 & 88.65 & 10.39 & 81.18 & 8.43 \\
\hline 3 & 2.2 .2000 & 15 & j.v.780-H/2000(V) & -13.67 & -54.28 & 75.28 & 22.97 & 69.94 & 7.09 \\
\hline 4 & 17.5 .2000 & 3 & j.v.3008-H/00 & -8.50 & - & 94.61 & 1.76 & 30.87 & 67.37 \\
\hline 5 & 18.5 .2000 & 15 & j.v.3007-H/00 & -11.70 & - & 91.16 & 1.79 & 18.45 & 79.76 \\
\hline 6 & 17.7 .2000 & 15 & j.v.3010-H/00 & -10.00 & -56.90 & 87.71 & 8.87 & 63.33 & 27.8 \\
\hline 7 & 25.7 .2000 & 15 & j.v.3011-H/00 & -9.10 & - & 92.53 & 2.44 & 30.22 & 67.34 \\
\hline 8 & 25.7 .2000 & 3 & j.v.3013-H/00 & -11.30 & -49.26 & 48.38 & 51.6 & 48.36 & 0 \\
\hline 9 & 22.8 .2000 & 15 & j.v.3016-H/00 & -9.69 & -39.85 & 96.63 & 1.83 & 52.45 & 45.73 \\
\hline 10 & 22.8 .2000 & 15 & j.v.3018-H/00 & -10.20 & - & 100.00 & 0 & 45.36 & 54.64 \\
\hline 11 & 26.9 .2000 & 15 & j.v.3017-H/00 & -11.48 & - & 91.60 & 5 & 54.49 & 40.5 \\
\hline 12 & 8.11 .2000 & 15 & j.v.3019-H/00 & - & -59.86 & 71.16 & 28.38 & 70.01 & 1.61 \\
\hline 13 & 2.3 .2001 & 3 & j.v.969-T/01 & -4.68 & -47.90 & 89.54 & 7.71 & 65.97 & 26.32 \\
\hline 14 & 24.5 .2001 & 3 & j.v.971-T/01 & -3.55 & -68.24 & 92.88 & 5.47 & 71.31 & 23.22 \\
\hline 15 & 24.5 .2001 & 3 & j.v.977-I/01 & -3.50 & -67.95 & 92.94 & 5.39 & 70.91 & 23.7 \\
\hline 16 & 7.6 .2001 & 3 & j.v.978-V/01 & -2.70 & -55.54 & 69.72 & 28.27 & 65.1 & 6.63 \\
\hline 17 & 28.9 .2001 & & št.10 & -8.50 & -59.70 & 35.81 & 64.2 & 35.81 & 0 \\
\hline 18 & 28.9 .2001 & & št.11 & -7.76 & -58.80 & 53.63 & 0 & 0 & 0 \\
\hline 19 & 28.9 .2001 & & št.3 & -8.26 & -64.29 & 96.07 & 0 & 0 & 0 \\
\hline 20 & 28.11 .2001 & & št.11 & -9.35 & -55.60 & 50.92 & 49.08 & 50.92 & 0 \\
\hline 21 & 28.11 .2001 & & št.3 & -8.40 & - & 81.15 & 3.41 & 81.15 & 15.44 \\
\hline 22 & 23.1 .2002 & & št.3 & -11.40 & - & 77.10 & 22.9 & 77.1 & 0 \\
\hline 23 & 23.1 .2002 & & št.7 & -4.20 & -42.50 & 69.79 & 0 & 0 & 0 \\
\hline 24 & 28.3.2002 & & št. 6 & -9.95 & -53.50 & 23.05 & 76.95 & 23.05 & 0 \\
\hline 25 & 28.3 .2002 & & št.7 & -5.00 & -71.70 & 47.26 & 52.74 & 47.26 & 0 \\
\hline 26 & 26.4 .2002 & & št.4 & -4.40 & -62.40 & 31.60 & 68.39 & 31.6 & 0 \\
\hline 27 & 31.5 .2002 & & št.1 & -0.03 & -47.70 & 97.06 & 2.94 & 97.06 & 0 \\
\hline 28 & 31.5 .2002 & & št.11 & 2.84 & -57.70 & 96.63 & 3.37 & 96.63 & 0 \\
\hline 29 & 31.5 .2002 & & št. 4 & -5.85 & -68.60 & 55.52 & 44.48 & 55.52 & 0 \\
\hline 30 & 31.5.2002 & & št.7 & -3.31 & -68.60 & 83.44 & 16.56 & 83.44 & 0 \\
\hline 31 & 31.5 .2002 & & št. 9 & -1.60 & -58.70 & 97.77 & 2.23 & 97.77 & 0 \\
\hline 32 & 28.6 .2002 & & št.13 & 2.91 & -49.10 & 94.08 & 5.92 & 94.08 & 0 \\
\hline 33 & 28.6.2002 & & št.7 & -4.00 & -70.50 & 41.82 & 58.18 & 41.82 & 0 \\
\hline 34 & 1.7 .2002 & & št.8 & -2.07 & -40.00 & 96.68 & 3.32 & 96.68 & 0 \\
\hline 35 & 23.7 .2002 & & št.1 & -14.80 & -67.05 & 94.55 & 5.49 & 94.55 & 0 \\
\hline 36 & 23.7 .2002 & & št. 4 & -4.60 & - & 92.50 & 7.5 & 92.5 & 0 \\
\hline 37 & 24.7 .2002 & & št.13 & -2.15 & -55.45 & 76.24 & 23.76 & 76.24 & 0 \\
\hline 38 & 17.10 .2002 & 15 & j.v.3096+5/02 & -8.90 & -47.40 & 39.98 & 60.03 & 39.98 & 0 \\
\hline 39 & 17.10 .2002 & 15 & j.v.993-+60/02 & -3.00 & - & 100.00 & 0 & 77.95 & 22.05 \\
\hline 40 & 24.10 .2002 & 15 & j.v.3101+5/02 & -7.10 & -29.90 & 61.50 & 38.5 & 61.49 & 0 \\
\hline 41 & 6.11 .2002 & 15 & j.v.994-+-0/02 & -2.41 & - & 98.31 & 1.45 & 84.55 & 14 \\
\hline 42 & 29.1 .2003 & 3 & j.v.3119-T/02 & -9.10 & -50.00 & 86.58 & 13.42 & 86.6 & 0 \\
\hline 43 & 18.4 .2003 & 15 & j.v.3133-H/03 & -8.20 & -34.20 & 65.74 & 34.26 & 65.74 & 0 \\
\hline 44 & 18.4 .2003 & 15 & j.v.3134-H/03 & -9.70 & -45.00 & 65.30 & 34.7 & 65.3 & 0 \\
\hline 45 & 14.6 .2003 & 15 & j.v.3135-H/03 & -5.90 & -32.00 & 52.10 & 47.9 & 52.1 & 0 \\
\hline
\end{tabular}




\begin{tabular}{|c|c|c|c|c|c|c|c|c|c|}
\hline No. & Date & $\begin{array}{l}\text { Length } \\
\text { (m) }\end{array}$ & Borehole & $\begin{array}{l}\delta^{13} C_{\text {co2 }} \\
(\% 0)\end{array}$ & $\begin{array}{l}\delta^{13} \mathrm{C}_{\mathrm{cH} 4} \\
(\% 0)\end{array}$ & $\begin{array}{l}\text { CDMI } \\
(\%)\end{array}$ & $\mathrm{CH}_{4}(\%)$ & $\begin{array}{l}\mathrm{CO}_{2} \\
(\%)\end{array}$ & $\begin{array}{l}\mathrm{N}_{2} \\
(\%)\end{array}$ \\
\hline 46 & 17.9 .2004 & 15 & j.v.3231+8-GM/04 & -9.60 & -39.20 & 77.68 & 22.32 & 77.67 & 0 \\
\hline 47 & 28.9.2004 & 15 & j.v.3097+5/02 & -2.40 & -52.70 & 32.40 & 67.6 & 32.4 & 0 \\
\hline 48 & 28.9 .2004 & 9 & j.v.3099+5/02 & -1.00 & -49.20 & 28.10 & 71.9 & 28.1 & 0 \\
\hline 49 & 6.10 .2004 & 15 & j.v.3233+2-GM/04 & -5.20 & -58.50 & 44.80 & 55.2 & 44.8 & 0 \\
\hline 50 & 6.10 .2004 & & komora & -4.50 & -58.90 & 40.70 & 46.2 & 40.7 & 13.1 \\
\hline 51 & 6.10 .2004 & & št.11 & -5.00 & -54.10 & 49.90 & 49.9 & 50.1 & 49.9 \\
\hline 52 & 14.10 .2004 & & št.11 & -13.00 & -51.70 & 68.80 & 14.6 & 68.8 & 16.6 \\
\hline 53 & 19.1 .2005 & 15 & j.v.1021+2-GM/04 & -6.20 & -54.80 & 60.35 & 38.9 & 59.2 & 1.9 \\
\hline 54 & 19.1.2005 & & št.11 & -6.20 & -44.40 & 61.33 & 37.7 & 59.8 & 2.5 \\
\hline 55 & 26.1 .2005 & & št.11 & -1.50 & -56.40 & 53.80 & 46.2 & 53.8 & 0 \\
\hline 56 & 3.2 .2005 & & št.11 & -3.70 & -37.40 & 62.70 & 37.3 & 62.7 & 0 \\
\hline 57 & 18.2 .2005 & & št.11 & -2.20 & -59.90 & 1.04 & 87.9 & 0.92 & 11.2 \\
\hline 58 & 14.4 .2005 & & št.11 & -4.31 & -63.70 & 25.05 & 74.95 & 25.05 & 0 \\
\hline 59 & 6.5 .2005 & 10 & $\begin{array}{l}\text { j.v.3268+60- } \\
\text { GM/05 }\end{array}$ & -11.90 & -25.00 & 83.61 & 12.79 & 65.25 & 22 \\
\hline 60 & 6.10 .2005 & 15 & j.v.3298+2-GM/05 & -7.60 & -49.40 & 50.31 & 41.69 & 42.21 & 16.08 \\
\hline 61 & 6.10 .2005 & 15 & $\begin{array}{c}\text { j.v.3299+60- } \\
\text { GM/05 }\end{array}$ & -4.70 & -57.20 & 29.20 & 70.8 & 29.2 & 0 \\
\hline 62 & 20.10 .2005 & 15 & j.v.3100+5/02 & -4.70 & -58.70 & 25.43 & 69.78 & 23.8 & 6.4 \\
\hline 63 & 20.10 .2005 & & št.11 & -8.20 & -51.20 & 53.48 & 46.52 & 53.48 & 0 \\
\hline 64 & 26.10 .2005 & 15 & j.v.3292+2-GM/05 & -10.30 & -56.00 & 33.33 & 45.43 & 22.71 & 31.84 \\
\hline 65 & 26.10 .2005 & 15 & j.v.3300+2-GM/05 & -5.10 & -63.80 & 44.95 & 46.93 & 38.32 & 14.74 \\
\hline 66 & 26.10 .2005 & 10 & $\begin{array}{l}\text { j.v.3301+60- } \\
\text { GM/05 }\end{array}$ & -10.50 & -56.50 & 33.92 & 33.31 & 17.1 & 49.6 \\
\hline 67 & 3.2 .2006 & & št.4 & -12.40 & -74.90 & 88.33 & 11.67 & 88.33 & 0 \\
\hline 68 & 5.7 .2006 & 15 & jpk-1/06+2 & -3.16 & -68.60 & 80.15 & 19.85 & 80.14 & 0 \\
\hline 69 & 5.7 .2006 & 10 & jpk-2/06+40 & -3.08 & -70.30 & 82.29 & 16.55 & 76.92 & 6.51 \\
\hline 70 & 20.9 .2006 & 15 & j.v.1059-GM/05 & -2.79 & - & 100.00 & 0 & 100 & 1.34 \\
\hline 71 & 20.9 .2006 & 15 & j.v.1060-GM/05 & -2.82 & - & 100.00 & 0 & 100 & 3.68 \\
\hline 72 & 21.2.2007 & 15 & jpk-4/06+20 & -3.57 & -65.60 & 76.53 & 23.22 & 75.73 & 1.03 \\
\hline 73 & 1.3 .2007 & 6 & jpk-3/06+2 & -6.43 & -54.40 & 33.24 & 66.75 & 33.24 & 0 \\
\hline 74 & 20.3 .2007 & & št. 4 & -3.36 & -66.50 & 51.45 & 48.55 & 51.45 & 0 \\
\hline 75 & 20.3 .2007 & & št.8 & -8.23 & -66.70 & 48.43 & 51.57 & 48.43 & 0 \\
\hline 76 & 21.3.2007 & & št.6 & -3.52 & -66.20 & 51.38 & 48.62 & 51.38 & 0 \\
\hline 77 & 21.3.2007 & & št.7 & -3.37 & -66.60 & 50.19 & 49.81 & 50.19 & 0 \\
\hline 78 & 28.3.2007 & & št.11 & -3.54 & -66.10 & 51.94 & 48.06 & 51.94 & 0 \\
\hline 79 & 28.3.2007 & & št.13 & -3.35 & -65.00 & 48.93 & 51.07 & 48.93 & 0 \\
\hline 80 & 17.7 .2007 & 3 & j.v. 3343-T/07 & 0.61 & -68.90 & 19.30 & 77.48 & 18.53 & 3.97 \\
\hline 81 & 10.9 .2007 & 20 & jpk-5/07 & -1.36 & - & 90.96 & 7 & 70.4 & 22.6 \\
\hline 82 & 10.9 .2007 & 20 & jpk-7/07 & -4.16 & -74.86 & 55.16 & 23.9 & 29.4 & 46.7 \\
\hline 83 & 5.10 .2007 & 20 & jpk-10/07 & -5.04 & -63.04 & 53.93 & 38.7 & 45.3 & 16 \\
\hline 84 & 5.10 .2007 & 10 & jpk-11/07 & -4.75 & -62.99 & 52.41 & 40.5 & 44.6 & 14.9 \\
\hline 85 & 5.10 .2007 & 10 & jpk-12/07 & 3.19 & -62.89 & 5.21 & 65.5 & 3.6 & 30.9 \\
\hline 86 & 5.10 .2007 & 20 & jpk-9/07 & -4.83 & -57.52 & 68.17 & 26.9 & 57.6 & 15.5 \\
\hline 87 & 18.7.2008 & 3 & $\begin{array}{l}\text { k.-35c (bivša } \\
\text { odvozna) }\end{array}$ & -4.40 & -58.20 & 71.09 & 28.75 & 70.71 & 0.53 \\
\hline 88 & 26.11 .2008 & 15 & jpk-18/08 & -5.30 & -59.10 & 71.11 & 28.89 & 71.1 & 0 \\
\hline 89 & 26.11 .2008 & 15 & jpk-19/08 & -5.40 & -59.30 & 71.89 & 28.11 & 71.88 & 0 \\
\hline
\end{tabular}




\begin{tabular}{|c|c|c|c|c|c|c|c|c|c|}
\hline No. & Date & $\begin{array}{l}\text { Length } \\
\text { (m) }\end{array}$ & Borehole & $\begin{array}{c}\delta^{13} \mathbf{C}_{\mathrm{co2}} \\
(\% 0)\end{array}$ & $\begin{array}{c}\delta^{13} \mathrm{C}_{\mathrm{CH} 4} \\
(\% 0)\end{array}$ & $\begin{array}{c}\text { CDMI } \\
\text { (\%) }\end{array}$ & $\mathrm{CH}_{4}(\%)$ & $\begin{array}{l}\mathrm{CO}_{2} \\
(\%) \\
\end{array}$ & $\begin{array}{l}\mathrm{N}_{2} \\
(\%) \\
\end{array}$ \\
\hline 90 & 26.11 .2008 & 10 & jpk-21/08 & -11.40 & -37.20 & 73.63 & 26.37 & 73.63 & 0 \\
\hline 91 & 11.12.2008 & 10 & jpk-20/08 & -12.00 & -38.40 & 70.59 & 29.41 & 70.58 & 0 \\
\hline 92 & 7.9 .2009 & 20 & jpk-22/09-II & -0.20 & -40.75 & 53.42 & 46.58 & 53.42 & 0 \\
\hline 93 & 7.9.2009 & 14 & jpk-23/09-II & 2.85 & -40.62 & 54.90 & 45.10 & 54.90 & 0 \\
\hline 94 & 8.7 .2009 & 9 & jpk-26/09 & -1.60 & -22.80 & 64.91 & 35.09 & 64.91 & 0 \\
\hline 95 & 4.2 .2009 & 3 & vrtina 1 & -10.82 & -38.80 & 83.34 & 16.66 & 83.33 & 0 \\
\hline 96 & 18.2 .2010 & 3 & K.-120B ODVOZ & -6.70 & -40.80 & 93.64 & 6.36 & 93.6 & 0 \\
\hline 97 & 18.2 .2010 & 2.3 & K.-120B ODVOZ & -6.00 & -36.70 & 88.89 & 11.11 & 88.89 & 0 \\
\hline 98 & 18.2 .2010 & 1.5 & K.-120B ODVOZ & -7.10 & -33.50 & 90.39 & 9.61 & 90.39 & 0 \\
\hline 99 & 25.3 .2010 & 3 & k.-50/B ODVOZ & -4.80 & -52.80 & 93.90 & 6.1 & 93.9 & 0 \\
\hline 100 & 25.3 .2010 & 3 & k.-50/B ODVOZ & -3.50 & -43.50 & 85.13 & 14.87 & 85.13 & 0 \\
\hline 101 & 21.4 .2010 & 3 & k.-50/B ODVOZ & -7.80 & - & 95.79 & 4.21 & 95.79 & 0 \\
\hline 102 & 21.5 .2010 & 3 & k.-50/B ODVOZ & -8.10 & - & 97.94 & 2.06 & 97.94 & 0 \\
\hline 103 & 18.8 .2010 & 20 & jpk-30/10 & 1.80 & -30.97 & 57.80 & 42.2 & 57.8 & 0 \\
\hline 104 & 27.8 .2010 & 20 & jpk 31/10 & -9.10 & -19.82 & 69.30 & 30.7 & 69.3 & 0 \\
\hline 105 & 8.9 .2010 & 20 & jpk 32/10 & -4.80 & -61.20 & 72.70 & 27.3 & 72.7 & 0 \\
\hline 106 & 16.9 .2010 & 25 & jpk 34/10 & -4.70 & -59.80 & 70.25 & 29.75 & 70.24 & 0 \\
\hline 107 & 4.10 .2010 & 25 & jpk-28/10 & -7.10 & -58.20 & 72.41 & 27.6 & 72.44 & 0 \\
\hline 108 & 4.10 .2010 & 25 & jpk-29/10-II & -8.70 & -48.60 & 82.10 & 17.9 & 82.1 & 0 \\
\hline 109 & 11.11 .2010 & 20 & jpk 35/10 & 1.00 & -66.30 & 93.10 & 6.9 & 93.1 & 0 \\
\hline 110 & 11.11 .2010 & 20 & jpk 36/10 & -6.20 & -57.50 & 77.30 & 22.7 & 77.3 & 0 \\
\hline 111 & 4.1 .2013 & 25 & JPK $62+10^{\circ}$ & -8.00 & -48.20 & 57.50 & 42.5 & 57.5 & 0 \\
\hline 112 & 22.2 .2013 & 25 & JPK 56 & -3.40 & -42.90 & 36.40 & 63.6 & 36.4 & 0 \\
\hline 113 & 8.3.2013 & 25 & JPK $63+10^{\circ}$ & -2.20 & -34.40 & 95.50 & 4.5 & 95.5 & 0 \\
\hline 114 & 3.10 .2013 & & JPK $70+10^{\circ}$ & -8.30 & -51.90 & 42.31 & 57.55 & 42.2 & 0.27 \\
\hline 115 & 5.12 .2013 & & $\mathrm{JPK} 73+10^{\circ}$ & -8.70 & -53.10 & 92.44 & 7.5 & 91.7 & 0.81 \\
\hline 116 & 11.7 .2014 & 25 & JPK $77+10^{\circ}$ & -6.50 & -54.20 & 66.80 & 31.04 & 62.44 & 6.51 \\
\hline 117 & 20.10 .2014 & 25 & $\mathrm{JPK} 78+10^{\circ}$ & -9.70 & -48.40 & 67.43 & 29.8 & 61.7 & 8.5 \\
\hline 118 & 22.4 .2015 & 25 & JPK $82+10^{\circ}$ & -1.50 & -50.20 & 90.91 & 9.09 & 90.9 & 0 \\
\hline 119 & 21.9 .2015 & 25 & JPK $87+10^{\circ}$ & -4.58 & -29.45 & 67.86 & 32.38 & 68.37 & 0 \\
\hline
\end{tabular}

$\delta^{13} \mathrm{C}_{\mathrm{CH} 4}$ values are lower (less than $50 \%$ ), indicating that the $\mathrm{CH}_{4}$ is bacterial in origin (Whiticar, 1996, 1999; Scott, 1999; Strapoć et al., 2011). At the southern part of the basin, values up to $-10 \%$ are observed, indicating thermogenic $\mathrm{CH}_{4}$ (Kanduč et al., 2012). Higher $\delta^{13} \mathrm{C}_{\mathrm{CH} 4}$ values (values up to $-10 \%$, Figure $3 \mathrm{~B}$ ) in lowrank coals in Velenje Basin are attributed to the bacterial activity in a Ca-rich alkaline environment, formed via the $\mathrm{CO}_{2}$ reduction process.

Methane in the Velenje Basin was formed via the two methanogenesis pathways $\left(\mathrm{CO}_{2}\right.$ reduction and acetate fermentation). These pathways, and the origin of coalbed gas at the different excavation fields, were described in detail in the study by Sedlar et al. (2014).
Figure 4 shows the CDMI values, measured at the locations (Figure 4A) and on the interpolated map (Figure 4B). From the direct values at the locations, CDMI is seen to be lower in the northern part of the Velenje Coal Basin (less than 70\%). The spatial distribution becomes even more visible on the interpolated map, where higher values (greater than $70 \%$ ) are found in the southern part of the basin close to the Šoštanj Fault (Figure 1). Even the orientation of the higher values in the direction parallel to faults is visible, so the Šoštanj Fault has a visible influence on the higher $\mathrm{CO}_{2}$ contributions in regard to the $\mathrm{CH}_{4}$ values, as calculated from the CDMI. It has to be emphasised that $\mathrm{CO}_{2}$ is used as a critical parameter for gas outbursts 

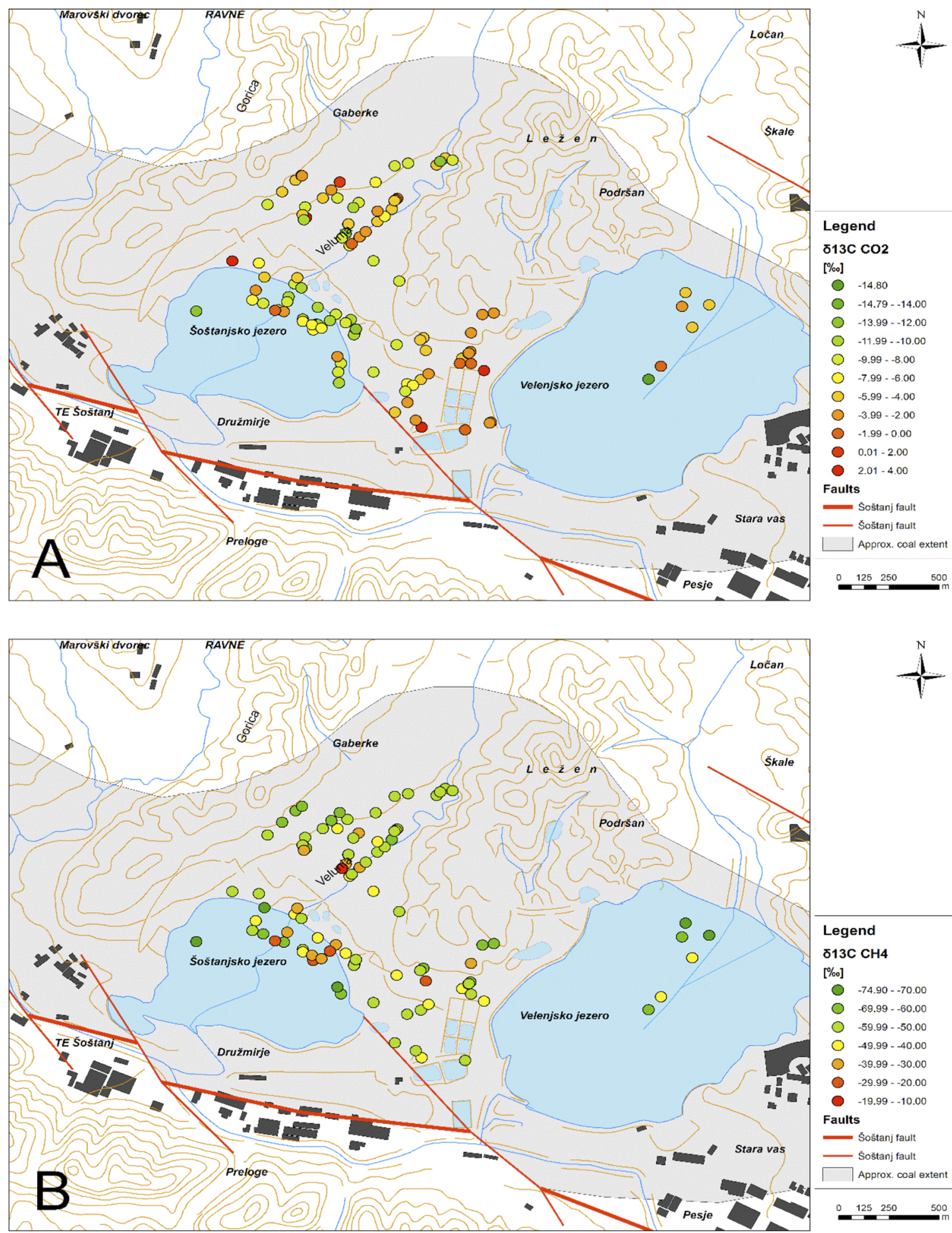

Figure 3: $A: \delta^{13} C_{\mathrm{CO} 2}$ and $B: \delta^{13} C_{C H 4}$ values at the active excavation fields since the year 2000. Topographic maps based on the vector DTK50 data, The Surveying and Mapping Authority of the Republic of Slovenia (http://www.gu.gov.si/en/). 

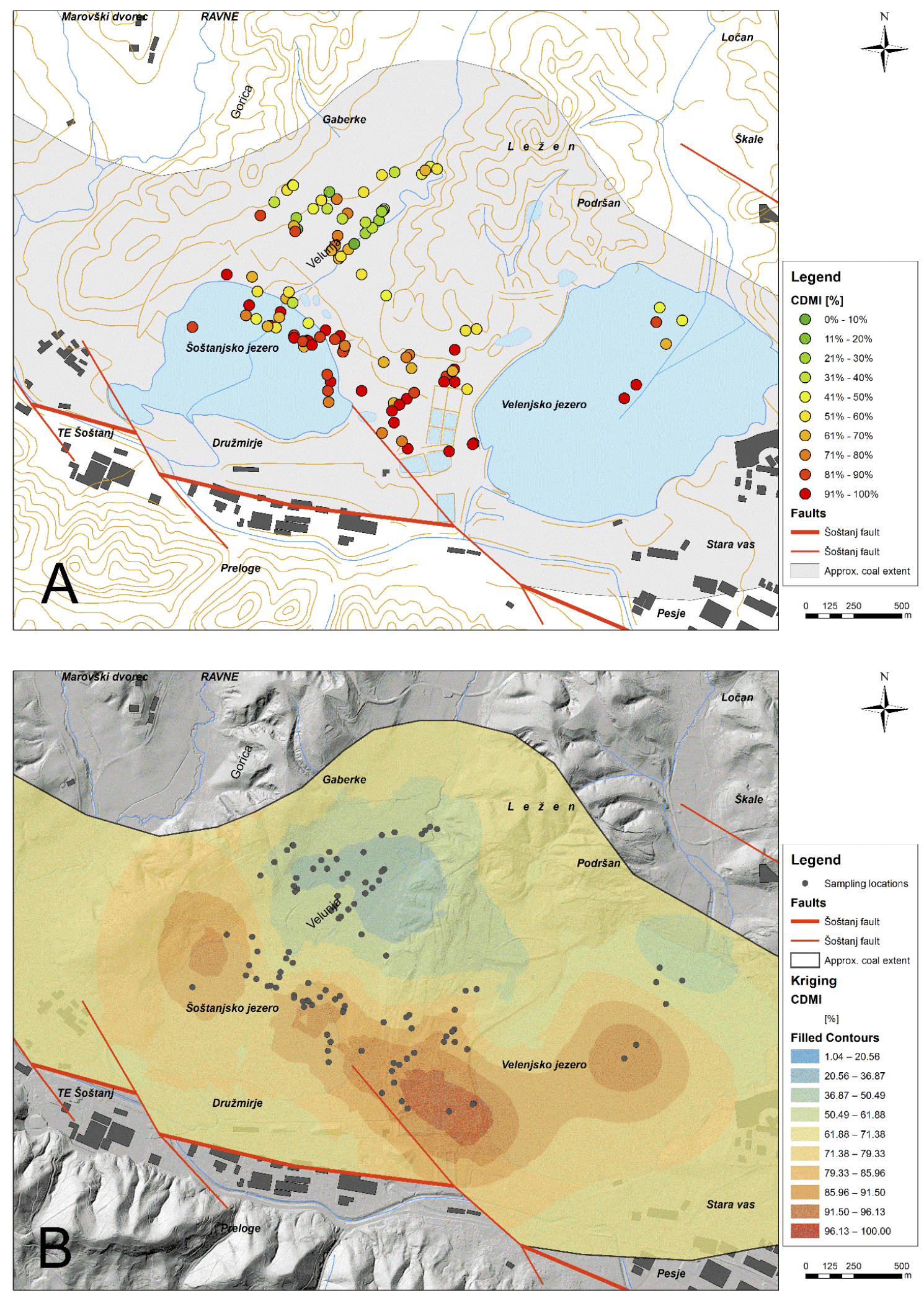

Figure 4: A: Carbon dioxide-methane index (CDMI) and B: Interpolated map of CDMI values for the active excavation fields since the year 2000 . 
occurring not just in Velenje Basin, but also in other coal basins (Sydney and Bowen basins, Australia basins). Higher concentrations of $\mathrm{CO}_{2}$ and, consequently, higher values of CDMI in relation to the active fault zones were also observed in the Bowen and Sydney basins (Smith and Gould, 1980).

\section{Conclusions}

We used geochemical $\left(\mathrm{CH}_{4}, \mathrm{CO}_{2}\right)$ and isotope tracers $\left(\delta^{13} \mathrm{C}_{\mathrm{CO} 2}\right.$ and $\left.\delta^{13} \mathrm{C}_{\mathrm{CH} 4}\right)$ for the geochemical and isotopic characterisation of coalbed gases from the active excavation fields Preloge and Pesje in the Velenje Basin since the year 2000. All georeferenced, geochemical and isotopic data from the available database have been combined spatially in a GIS environment (JamTveg GIS; Verbovšek, 2010; Verbovšek and Vrabec, 2012) to obtain the distribution of the investigated parameters. The CDMI is introduced as a crucial parameter of zones dangerous for gas outbursts. Areas with high CDMI have, consequently, high $\mathrm{CO}_{2}$ concentrations and are areas with greater gas outburst potential.

The CDMI ranges from $0 \%$ to $100 \%$. At the northern part of the basin, the CDMI is lower (values less than 70\%) and, at the southern part, the value is higher (the vicinity of the Šoštanj Fault), indicating a greater potential for gas outburst.

$\delta^{13} \mathrm{C}_{\mathrm{CH} 4}$ values range from $-70 \%$ to $-50 \%$, indicating a bacterial gas origin. Higher $\delta^{13} \mathrm{C}_{\mathrm{CH} 4}$ values, up to $-10 \%$, are characteristic of thermogenic gas, but appear in low-coal ranks and are attributable to bacterial gas formed via $\mathrm{CO}_{2}$ reduction. $\delta^{13} \mathrm{C}_{\mathrm{CH} 4}$ values around $-70 \%$ indicate bacterial gas, formed via acetate fermentation.

$\delta^{13} \mathrm{C}_{\mathrm{CO2}}$ values range from $-14.8 \%$ o to $+4.0 \%$, indicating bacterial gas. Values of $-14 \%$ are characteristic of organic degradation, while values of $+4 \%$, observed at the southern part of the basin, are characteristic of bacterial gas formed via $\mathrm{CO}_{2}$ reduction.

From all the geochemical and isotopic results gathered since the year 2000 , it can be concluded that the origin of the coalbed gases in Velenje Basin is bacterial (formed via $\mathrm{CO}_{2}$ reduction or acetate fermentation). The distribution of gases is also dependent on the geological characteristics of the basin and its formation. Biogeochemical processes such as the gelification and mineralization observed in lignite are typical of Ca-rich alkaline environments and were also confirmed from the stable isotope composition. Moreover, petrified woods (composed mostly of calcite) found in coal seams are typically bacterially degraded, which is reflected in the isotope composition. All these facts confirm the conclusion that the distribution of coalbed gas trapped in the coal matrix originated in the early diagenesis of the 160-m-thick coalbed seam known worldwide as a unique phenomenon.

Geochemical and isotopic investigations of coalbed gases have been ongoing since the year 2000 at the active excavation fields in Velenje Coalmine d.d. These investigations provide new understanding and insights into the gas composition, the origin of gas components, gas migration pathways and the distribution of gases, in addition to being important for the development of coalbed methane (CBM) technology and for safety reasons.

The spatial distribution of CDMI, in the context of the relative values of $\mathrm{CO}_{2}$ and $\mathrm{CH}_{4}$, clearly shows the influence of the active Šoštanj Fault, as the CDMI values are higher in the southern part of the Velenje Basin close to the fault. In addition, the orientation of higher values is spatially distributed and parallel to the faults, indicating the influence of the CDMI on gas distribution.

Further investigations need to include more spatially distributed data for a more sound interpretation and further analysis of data.

\section{Acknowledgements}

This study was conducted within the frameworks of Project L1-5451, funded by the Slovenian Research Agency (ARRS) and the Velenje Coalmine d.d., as well as of research projects cofounded by Velenje Coalmine d.d. from the year 2000. The authors are very grateful to Mr. Ivo Zadnik, Mr. Tedej Zagoričnik and Mr. Stojan Žigon for technical support and assistance in the field sampling and laboratory work. We thank Roger Pain for linguistic corrections. 


\section{References}

[1] Atkins, P.W. (1994): Physical Chemistry, fifth ed. Oxford Univ. Press, Oxford, pp. 1031.

[2] Brezigar, A. (1987): Coal seam of the Velenje coal mine. Geologija 28, pp. 319-336 (in Slovene with English summary).

[3] Coplen, T.B. (1996): New guidenices for reporting stable hydrogen, carbon and oxygen isotopes ratio data. Geochimica Cosmochimica Acta, 60, pp. 390-3360.

[4] Faiz, M, Hendry, P. (2006): Significance of microbial activity in Australian coal bed methane reservoirs-a review. Bull. Can. Pet. Geol., 54, pp. 261-272.

[5] Jamnikar, S. (2016): An investigation into the flow of gases around longwall top coal caving faces and gas drainage trials at Coal Mine Velenje: doctoral dissertation = Raziskava plinskih migracij okoli širokočelnih odkopov in razplinjevanje $v$ Premogovniku Velenje: doktorska disertacija. Ljubljana, pp. 111.

[6] Jeromel, G., Medved, M., Likar, J. (2010): An analysis of the geomechanical processes in coal mining using the Velenje mining method. Acta Geotechnica Slovenica, 7 , pp. 31-45.

[7] Kanduč T., Grassa F., McIntosh J., Stibilj V., Ulrich-Supovec M., Supovec I., Jamnikar S. (2014): A geochemical and stable isotope investigation of groundwater/surface-water interactions in the Velenje Basin, Slovenia. Hydrogeology Journal, 22, pp. 971-984.

[8] Kanduč, T. \& Pezdič, J. (2005): Origin and distribution of coalbed gases from the Velenje Basin, Slovenia. Geochemical Journal, 39, pp. 397-409.

[9] Kanduč, T. (2004): Isotopic characteristics of coalbed gases in Velenje Basin. Master Thesis. Ljubljana: University of Ljubljana 2004; pp. 78 (in Slovene).

[10] Kanduč, T., Žula, J., Zavšek, S. (2011): Tracing coalbed gas dynamics and origin of gases in advancement of the working faces at mining areas Preloge and Pesje, Velenje basin. RMZ-Mater. Geoenvironment 58, pp. 373-288.

[11] Kanduč, T., Markič, M., Zavšek, S., McIntosh, J. (2012): Methanogenesis in the Pliocene Velenje Coal Basin, Slovenia, inferred from stable carbon isotopes. International Journal of Coal Geology, 89, pp. 70-83.

[12] Kanduč, T., Grassa F., Sedlar J., Zavšek S. (2015): Geochemical and isotopic characterization of coalbed gases in active excavation fields at Preloge and Pesje (Velenje Basin) mining areas. RMZ-Mater. Geoenvironment 62, pp. 21-35.

[13] Kočar, F., Veselič, M., Ribičič, M., Mramor J. (1987): Kriteriji varnega odkopavanja premoga pod vodonos- nimi plastmi v jamah RLV. Interno gradivo, Titovo Velenje, Rudnik lignita Velenje.

[14] Kočar, F., Veselič, M., Ribičič, M., Mramor, J. (1989): Safety criteria of coal excavation under aquifer layers in Velenje Coal Mine. Mining and metallurgy quarterly: periodical for geology, mining and metallurgy, 36, Vol. 2, 421-438.

[15] Kotarba, M.J. (2001): Composition and origin of coalbed gases in the Upper Silesian and Lublin basins, Poland. Organic Geochemistry, 32, pp. 163-180.

[16] Lenart, M. (1996). Velenjska odkopna metoda, RP 36/95 LM, Premogovnik Velenje.

[17] Markič, M., Sachsenhofer, R. (1997): Petrographic composition and depositional environments of the Pliocene Velenje lignite seam (Slovenia). International Journal of Coal Geology 33(3), pp. 229-254.

[18] O'Neil, J.R. (1979): Stable Isotope Geochemistry of Rocks and Minerals. - V: Lectures in Isotope Geology, Jager, E., Hunzinger, J.C., (Eds). - Springer Verlag, pp. 235-263, Berlin.

[19] Scott, A.R. (1999): Improving gas recovery with microbially enhanced coalbed methane. In: Mastalerz, M., Glikson, M., Golding, S.D. (Eds.), Coalbed Methane: Scientific Environmental and Economic Evaluation. Kluwer, Dordrecht, pp. 89-110.

[20] Sedlar J., Kanduč T., Jamnikar S., Grassa F., Zavšek S. (2014): Distribution, composition and origin of coalbed gases in excavation fields from the Pesje mining areas, Velenje Basin, Slovenia, International Journal of Coal Geology, 131, pp. 363-377.

[21] Smith, J.W. \& Gould, K.W. (1980): An isotopic study of the role of carbon dioxide in outbursts in coal mines. Geochemical Journal, 14, pp. 27-32.

[22] Smith, J.W., Pallaser, R. (1996): Microbial origin of Australian coalbed methane. American Association of Petroleum Geological Bulletin 80, pp. 891-897.

[23] Strapoć, D., Mastalerz, M., Dawson K., Macalady J., Callaghann A.V., Wawrick B., Turich, C., Ashby M. (2011): Biogeochemistry of microbial coal-bed methane. Ann. Rev. Earth Planet. Sci., 39, pp. 617-656.

[24] Urbanc J., Lajlar B. (2002). Interpretation of groundwater origin in the Velenje coal mine on the basis of isotope composition (in Slovene). Geologija, 45, pp. 595-598.

[25] Verbovšek, T. (2010): JamTveg GIS 2010; Ljubljana: Oddelek za geologijo, NTF, UL.

[26] Verbovšek, T., Vrabec, M. (2012): JamTveg GIS v.2 Ljubljana: Oddelek za geologijo, NTF, UL.

[27] Veselič M., Pezdič J. (1998): Hydrogeological aspects of lignite mine Velenje: environmental isotope study. RMZ - Materials \& Geoenvironment 45, pp. 192-196. 
[28] Vižintin, G., Kocjančič, M., Vulić, M. (2016): Study of Coal Burst Source Locations in the Velenje Colliery. Energies 2016, 9, 507.

[29] Vukelič, Ž., Dervarič, E., Šporin, J., Vižintin, G. (2016): The Development of Dewatering Predictions of the Velenje Coalmine. Energies 2016, 9, pp. 702.
[30] Whiticar, M.J. (1996): Stable isotope geochemistry of coals, humic kerogens and related natural gases. International Journal of Coal Geology, 32, pp. 191-215.

[31] Whiticar, M.J. (1999): Carbon and hydrogen isotope systematics of bacterial formation and oxidation of methane. Chemical Geology, 161, pp. 291-314. 
